\title{
IL-10 gene promoter polymorphisms and leprosy in a Colombian population sample
}

\author{
Nora Cardona-Castro1, Miryam Sánchez-Jiménez¹, Winston Rojas², Gabriel Bedoya-Berrío \\ ${ }^{1}$ Instituto Colombiano de Medicina Tropical-Universidad CES, Medellín, Colombia \\ ${ }^{2}$ Grupo GENMOL, Universidad de Antioquia, Medellín, Colombia
}

Introduction. Polymorphisms in promoters of genes code for cytokines that affect transcription levels. Several have been associated with leprosy patients that have functional and clinical implications.

Objective. Polymorphisms in the promoter of the $I L 10$ gene of leprosy patients will be compared frequencies in normal population.

Materials and methods. SNPs (single nucleotide polymorphism) -1082 A/G (rs1800896), -819C/T (rs1800871), and -592A/C (rs1800872) were identified in 100 leprosy patients and in a control group of 100 volunteers from a leprosy endemic region of Colombia.

Results. The genotypes $\mathrm{C} / \mathrm{C}$ and $\mathrm{C} / \mathrm{T}$ in the SNP -819 were associated together with leprosy (OR=4.34, $p<0.001$ ). Similarly, the genotypes $C / C$ and $C / A$ in the -592 SNP showed an association ( $O R=4.3, p<0.001$ ). The haplotypes $-819 \mathrm{C}-519 \mathrm{C}$ and $-1082 \mathrm{~A}-819 \mathrm{C}-592 \mathrm{C}$ showed significant association (OR=4.34, $p<0.001$ and $\mathrm{OR}=6.25, p<0.001)$ respectively. These haplotypes in homozygosis conditions were also associated with leprosy: $-819 \mathrm{C}-519 \mathrm{C} /-819 \mathrm{C}-519 \mathrm{C}(\mathrm{OR}=4.34, p<0.001),-1082 \mathrm{~A}-819 \mathrm{C}-592 \mathrm{C} /-1082 \mathrm{~A}$ $-819 \mathrm{C}-592 \mathrm{C}(\mathrm{OR}=1.90, p=0.04)$. The SNP -1082 was not associated with leprosy in this population.

Conclusions. The haplotypes associated with leprosy, -1082A-819C-592C/-1082A-819C-592C, have been reported as low producers of IL-10. Functionally, the low production of IL-10 may have immune response consequences and clinical implications. Additional haplotypes of IL-10 have been reported as markers for leprosy susceptibility or resistance in other ethnic populations. This suggests that differences in distribution of diverse IL-10 gene polymorphisms among ethnic groups may indicate important gene-disease associations.

Keywords: Leprosy, interleukin-10, cytokines; promoter regions, genetic; polymorphism, single nucleotide.

\section{Polimorfismos en el gen promotor de IL-10 en una muestra de pacientes colombianos con lepra}

Introducción. Se han reportado polimorfismos en los genes promotores que codifican para citocinas y que afectan los niveles de transcripción, con implicaciones clínicas y funcionales en pacientes con lepra.

Objetivo. Detectar los polimorfismos en el gen promotor de la interleucina 10 (IL-10), de los polimorfismos de un solo nucleótido (Single Nucleotide Polymorphisms, SNP) -1082 A/G (rs1800896), $-819 \mathrm{C} / \mathrm{T}$ (rs1800871) y -592A/C (rs1800872), en 100 pacientes con lepra y un grupo control de 100 voluntarios, de una región endémica de Colombia.

Resultados. Los haplotipos -819C-519C y-1082A-819C-592C mostraron asociación significativa con lepra: $\mathrm{OR}=4,34, \mathrm{p}=1 \times 10^{-3}$, y $\mathrm{OR}=6,25, \mathrm{p}=5 \times 10^{-4}$, respectivamente. Estos haplotipos en condiciones de homocigoto, están también asociados con lepra: -819C-519C/-819C-519C (OR=4,34 $\left.p=1 \times 10^{-3}\right)$, $-1082 \mathrm{~A}-819 \mathrm{C}-592 \mathrm{C} /-1082 \mathrm{~A}-819 \mathrm{C}-592 \mathrm{C}(\mathrm{OR}=1,90$ y $\mathrm{p}=0,04)$. EI SNP -1082 no se encontró asociado con lepra en esta población. Los genotipos C/C y C/T en el SNP -819, se encontraron asociados a lepra $\left(\mathrm{OR}=4,34, \mathrm{p}=1 \times 10^{-3}\right)$; de igual manera, los genotipos $\mathrm{C} / \mathrm{C}$ y $\mathrm{C} / \mathrm{A}$ en el SNP -592 mostraron asociación $\left(\mathrm{OR}=4,34, \mathrm{p}=1 \times 10^{-3}\right)$.

Conclusiones. El haplotipo que encontramos asociado con lepra, -1082A-819C-592C/-1082A-819C$592 \mathrm{C}$, se ha relacionado con baja producción de IL-10. Funcionalmente, esta baja producción de IL-10 puede tener consecuencias en la respuesta inmunitaria, además de implicaciones clínicas. Se han reportado diferentes haplotipos de IL-10 como marcadores de vulnerabilidad y resistencia de lepra en otras poblaciones, lo cual sugiere que las diferencias en la distribución de diversos polimorfismos del

\footnotetext{
Authors' contributions:

Nora Cardona-Castro designed the study and wrote the manuscript.

Miryam Sánchez-Jiménez performed the laboratory work.

Nora Cardona-Castro, Winston Rojas and Gabriel Bedoya-Berrío analyzed the results.
} 
gen de IL-10 entre grupos étnicos, es un factor importante al determinar la asociación entre enfermedad y genes.

Palabras clave: lepra, interleucina-10, citocinas, regiones promotoras genéticas, polimorfismo de nucleótido simple.

There are clinical and epidemiological evidences suggesting leprosy does not occur in most of the exposed individuals, this fact can be partly explained by their genetic background, implicating the participation of immune response genes (1). The identification of polymorphic variants located on different functional promoter regions for cytokine genes as TNF-a, IFN-g, IL-10, IL-6, and TGF-b1, have been associated with differential activation and cytokine levels (2-10). Variations in cytokines levels may have functional and clinical implications, a situation that has been confirmed in tissue transplants, autoimmune diseases and in some infectious diseases as leprosy (4,11-13).

IL-10, an immunoregulatory cytokine secreted by monocyte, macrophage, and $\mathrm{T}$ cells lineage, regulates T-helper 1 cytokines production contributing to the immune response, which is translated in control or persistence of the pathogens (14). Interleukin (IL)-10 gene polymorphisms have been analyzed in several populations demonstrating the association with leprosy (15-17), however results of previous works from different populations are variable (15-20).

For example, in an Indian population the -1082A/819C/-592C haplotype confers resistance to leprosy and the haplotype -1082A/-819T/-592A confers susceptibility (16), whereas in a Brazilian population from Rio de Janeiro the above mentioned haplotypes were not associated with leprosy (17), but the -819T allele was associated with leprosy susceptibility per se (18). Another study from Brazil with IL-10 extended haplotypes showed that the combination of $3575 \mathrm{~A} /-2849 \mathrm{G} /-2763 \mathrm{C} /-1082 \mathrm{G} /-$ $819 \mathrm{C}$ was associated with resistance, and $-3575 \mathrm{~T} /-$ 2849A/-2763C/-1082G/-819T was the susceptible haplotype, confirming the participation of $-819 \mathrm{~T}$ as a susceptibility allele (19). Major differences have been reported in IL-10 haplotypes tested in populations from different regions of the same

\footnotetext{
Correspondencia:

Nora Cardona-Castro, Instituto Colombiano de Medicina Tropical-Universidad CES, Carrera 43 A № 52 sur-99, Medellín, Colombia

Teléfono: (574) 305-3500, extensión 2297

ncardona@ces.edu.co, robledocardona@une.

Recibido: 20/06/11; aceptado:31/10/11
}

country, for example the study carried out in the Paraná State of Brazil, where the analysis of IL10 genotypes did not show any significant differences between leprosy patients and controls (7).

The variability of results found in IL-10 polymorphism associated to leprosy in different populations $(3,4)$ can be explained by genetic relationships mainly determined by the ethnic ancestry of the populations, fact demonstrated by the different geographic distributions of IL-10 haplotypes described in African, Asian and Caucasian populations $(3,4)$. The African population shows a more widespread distribution of IL-10 haplotypes than the Caucasian population, whereas the IL-10 haplotypes from a cohort from Vietnam were more restricted (4).

Identification of the host genes that influence host susceptibility/resistance in different endemic populations for leprosy will enable a greater understanding of disease pathogenesis. In turn, this should facilitate development of more effective and specific therapeutics and vaccines (21).

Based on the accumulated and divergent reports, and the lack of information in Colombian leprosy patients, we studied three polymorphisms in the promoter of $I L-10$ gene in one group of 100 Colombian leprosy patients to determine their distribution and compared with a control group of 100 volunteers.

The concept of using detection of gene polymorphisms to predict disease progression and early detection of leprosy susceptibility hold promise, as this assessment may play an important role in the global elimination of leprosy (22).

\section{Materials and methods \\ Patients}

Volunteer leprosy patients belonging to the Leprosy Program of four Colombian States (Antioquia, Córdoba, Bolívar, and Sucre) and a control group were studied. We attempted to control for racial differences that could confound the analysis, for this, we restricted recruitment to only white LatinAmerican patients (e.g. self-reported African and native-Indigenous racial groups not included). In total 100 leprosy patients and 100 controls were asked to participate after being fully informed of 
the study, and signed a consent form. Patients and controls underwent a thorough physical examination. Four skin smears and one nasal swab were obtained from each patient, and Ziehl Neelsen stain was performed (23). Briefly, slit skin smears (SSs) on a microscopic glass slide were obtained from the earlobes (2), margins of lesions (2), or elbows (2) by puncture with a sterile lancet. Nasal mucus swab (NS) (1) was also obtained using cotton swabs. The SSs were examined for the presence of acid fast bacilli (AFB) and a bacillary index $(\mathrm{BI})$ was performed.

\section{Case definition}

Tuberculoid leprosy (TT) was defined as a paucibacillary $(\mathrm{PB})$ patient, it means $\mathrm{Bl}=0$, with 1 to 5 hypo pigmented or erythematous sharply demarcated macules, with hypoesthesia, and involvement of one peripheral nerve identified by enlargement and/or localized pain $(24,25)$. Lepromatous leprosy (LL) was defined as a multibacillary $(\mathrm{MB})$ patient, $\mathrm{IB}>0$, with more than 5 skin lesions, nodules, plaques or papules, loss of sensitivity and compromised of several nerves $(24,25)$.

\section{Control definition}

Control group was composed by non-relatives household contacts of the leprosy case, living with the leprosy patient for more than two years under the same roof.

\section{Genotyping}

Blood samples were taken from each individual belonged to the cases and control groups by venipuncture in sterile conditions. DNA was isolated from $10 \mathrm{ml}$ of whole blood by the saltingout technique with EDTA, and adjusted to a tested concentration of 200ng/uL with distilled $\mathrm{H}_{2} \mathrm{O}$ (26). After DNA extraction amplification by polymerase chain reaction PCR-SSP methodology was performed, using Cytokine Genotyping Tray (One Lambda, Inc., Canoga Park, CA, USA) which provides sequence-specific oligonucleotide primers for amplification of selected IL-10 alleles. IL10 promoter polymorphisms rs1800896 $(-1082 A>G)$, rs1800871 (-819C>T) and rs1800872 $(-592 A>C)$ were typed following the manufacturer's instructions (27). Primer pairs were designed to have perfect matches only with a single allele or group of alleles. Under strictly controlled PCR conditions, perfectly matched primer pairs result in the amplification of target sequences (i.e. a positive result), while mismatched primer pairs do not result in amplification (i.e., a negative result). An internal control primer pair, that amplified a conserved region of human b-globin gene, was included to verify the integrity of each $\mathrm{PCR}$ reaction. Every test required 19 uL of DNA, 180 uL of D-Mix (PCR buffer, dNTPs, $\mathrm{MgCL} 2)$ and $1 \mathrm{uL}$ de Taq-Polimerase (5 U/uL) to perform the reaction (27).

After PCR process the amplified DNA fragments were separated by $2 \%$ agarose gel electrophoresis (140-150 V), visualized with ethidium bromide and exposed to ultraviolet light (27).

\section{Analysis of genetic data}

The Hardy-Weinberg equilibrium test for each SNP markers and the linkage disequilibrium between alleles at different loci (coefficients $r^{2}$ ) were carried out using the Arlequin v3.01 software (http://cmpg. unibe.ch/software/arlequin3). The chi square analysis was performed for allelic and genotypic distribution in TT vs. LL patients, and in cases vs control groups using the package SNPassoc included in free application R v2.10.1(http://www.rproject.org/), correction by age and sex was carried out. The frequencies of haplotypes were estimated with maximum likelihood based in the ExpectationMaximization (MS) algorithm implemented in the package haplo.stats of $R$ v2.10.1. We calculated the OR for alleles, genotypes and haplotypes with a confidence interval of $95 \%$ through the application package SNPassoc and PLINK v1.07.

\section{Ethical considerations}

All the patients and controls included in this study were volunteers; informed consent was obtained from all adult participants and from parents or legal guardians of minors, with the name of the appropriate institutional review board having approved the project. The procedures followed were in accordance with the ethical standards of the responsible committee on Instituto Colombiano de Medicina Tropical and Universidad CES, and with the Helsinki Declaration of 1975 , as revised in 1983 .

\section{Results}

\section{Studied population}

One hundred patients (75 TT and 25 LL) and 100 controls were studied. The youngest leprosy case was 11 and the oldest was 86 years old, 42.5 was the median age; 64 males and 36 females. Three cases classified as TT are under 16 . The mean age of control group is 41.3. The youngest control was 4 and the older 78 years old; 28 are male and 72 female. 


\section{Genotyping}

TT vs. LL patients: according to clinical classification we did not find any statistical difference among allelic frequencies found in TT and LL patients.

Cases vs. control group: non allelic association was found for any of three SNPs evaluated. However, when several heredity models were tested, we found that the SNP -1082 was not associated with leprosy in this population. In contrast, the genotypes $\mathrm{C} / \mathrm{C}$ and $\mathrm{C} / \mathrm{T}$ in the SNP -819 together, were associated with leprosy $\left(\mathrm{OR}=4.34 \mathrm{p}=1 \times 10^{-3}\right)$ and in the same way, the genotypes $\mathrm{C} / \mathrm{C}$ and $\mathrm{C} / \mathrm{A}$ in the $-592 \mathrm{SNP}$ showed association ( $\left.\mathrm{OR}=4.3 \mathrm{p}=1 \times 10^{-3}\right)$. The haplotypes -819C-519C and -1082A-819C-592C showed significant association $\left(O R=4.34 p=1 \times 10^{-3}\right.$ and $\mathrm{OR}=6.25 \mathrm{p}=5 \times 10^{-4}$ ) respectively (Table 1 ). These haplotypes in homozygosis conditions are also associated to leprosy, -819C-592C/-819C$592 \mathrm{C}\left(\mathrm{OR}=4.34 \mathrm{p}=1 \times 10^{-3}\right),-1082 \mathrm{~A}-819 \mathrm{C}-592 \mathrm{C} /-$ $1082 \mathrm{~A}-819 \mathrm{C}-592 \mathrm{C} \quad(\mathrm{OR}=1.90 \mathrm{p}=0.04), \quad-1082 \mathrm{~A}$ $\begin{array}{lllll}-819 T & -592 \mathrm{~A} /-1082 \mathrm{~A} & -819 \mathrm{~T} & -592 \mathrm{~A} & (\mathrm{OR}=0.25\end{array}$ $\mathrm{p}=0.0005)$ (Table 2).

\section{Discussion}

Polymorphisms located in the promoter region of genes that encode for cytokines have been associated with susceptibility, protection, immune response and clinical outcome of leprosy (1). However studies carried out in different populations show variable and non-consistent results $(7,13,16,17,28)$.

The haplotype that we found associated with leprosy, -1082A-819C-592C/-1082A-819C-592C, had been reported as low producer of IL- 10 . Functionally this low production of IL-10 may have immune response consequences and clinical implications. It is interesting to find out how these extended haplotypes influence the expression of IL-10 in this population in vivo conditions. We did not investigate the effect of IL-10 polymorphisms on cytokine production in current study.

In an Indian population the same haplotype that we found in current study, the $-1082 \mathrm{~A} /-819 \mathrm{C} /$ 592C haplotype confers resistance to leprosy and the haplotype $-1082 \mathrm{~A} /-819 \mathrm{~T} /-592 \mathrm{~A}$ confers susceptibility (16), whereas in a Brazilian population from Rio de Janeiro the above mentioned haplotypes were not associated with leprosy (17).

One fact that can influence the variable and nonconsistent results in IL-10 gene polymorphisms is that the extended haplo and genotypes are present at different frequencies in geographically separated populations, i.e., in African population the extended IL10 SNP haplotype was found to be more variable when compared to Caucasians as well as to Asians (4). In Colombia the population is the product of mix between American Indigenous, Africans and Caucasians (29), fact that can influence the differences of our results from other population reports.

With respect to the SNPs, we found the same association values for the SNPs -819 and -519 , fact that could be due to the LD found between them $\left(D^{\prime}=1, r=1\right)$, same explanation for the association found for the genotypes $\mathrm{C} / \mathrm{C}$ and $\mathrm{C} / \mathrm{T}$, in the SNP -819 which have been reported as leprosy susceptibility in other ethnic populations.

The IL-10 gene is located on chromosome 1 at 1q31-32 and is highly polymorphic $(3,4)$. Experiments have shown that the IL-10 haplo and genotypes influence on IL-10 expression (4),

Table 1. Frequencies of IL-10 alleles and genotypes in leprosy cases and controls

\begin{tabular}{|c|c|c|c|c|c|c|}
\hline IL 10 Loci & Allele/Genotype & Leprosy & $\begin{array}{l}\text { Controls } \\
n=100(\%)\end{array}$ & $\begin{array}{c}\text { OR } \\
n=100(\%)\end{array}$ & $95 \% \mathrm{Cl}$ & $\mathbf{p}$ \\
\hline \multirow[t]{5}{*}{-1082} & $A$ & 78,0 & 72,0 & 1.38 & $0.72-2.62$ & 0.3 \\
\hline & $\mathrm{G}$ & 22,0 & 28,0 & 0.73 & $0.38-1.38$ & 0.2 \\
\hline & AA & 63,0 & 59,0 & 1.13 & $0.67-2.09$ & 0.3 \\
\hline & $A G$ & 29,0 & 27,0 & 1.01 & $(0.53-1.89)$ & 0.4 \\
\hline & $\mathrm{GG}$ & 8,0 & 14,0 & 0.54 & $(0.21-1.37)$ & 0.39 \\
\hline \multirow[t]{4}{*}{-819} & C & 68,0 & 57,0 & 1.60 & $0.9-2.86$ & 0.1 \\
\hline & $\mathrm{T}$ & 32,0 & 43,0 & 0.62 & $0.35-1.11$ & 0.1 \\
\hline & $\mathrm{CC} / \mathrm{CT}$ & 92,0 & 74,0 & 4.34 & $1.73-9.45$ & 0.001 \\
\hline & TT & 8,0 & 26,0 & 0.25 & $(0.11-0.58)$ & 0.0005 \\
\hline \multirow[t]{4}{*}{-592} & $\mathrm{C}$ & 68,0 & 57,0 & 1.60 & $0.9-2.86$ & 0.07 \\
\hline & A & 32,0 & 43,0 & 0.62 & $0.35-1.11$ & 0.07 \\
\hline & $\mathrm{CC} / \mathrm{CA}$ & 92,0 & 74,0 & 4.34 & $1.73-9.45$ & 0.001 \\
\hline & $\mathrm{AA}$ & 8,0 & 26,0 & 0.25 & $(0.11-0.58)$ & 0.0005 \\
\hline
\end{tabular}


Table 2. Frequencies of extended IL-10 haplotypes in leprosy cases and controls

\begin{tabular}{lccccc}
\hline Extended haplotype & Cases & Controls & OR & $\mathbf{9 5 \%} \mathbf{C l}$ & $\mathbf{p}$ \\
\hline -1082-819-592/-1082-819-592 & & & & & \\
ACC/ACC & 28,0 & 17,0 & 1.90 & $0.96-3.75$ & 0.04 \\
ACC/ATA & 27,0 & 16,0 & 1.94 & $0.97-3.88$ & 0.04 \\
ATA/ATA & 8,0 & 26,0 & 0.25 & $0.11-0.58$ & 0.0005 \\
GCC/ACC & 9,0 & 9,0 & 1.0 & $0.38-2.63$ & 0.5 \\
GCC/ATA & 20,0 & 18,0 & 1.14 & $0.56-2.31$ & 0.4 \\
GCC/GCC & 8,0 & 14,0 & 0.53 & $0.21-1.34$ & 0.1 \\
\hline
\end{tabular}

nevertheless differences of IL-10 production are poorly characterized with respect to different stimuli $(3,4)$, i.e. M. leprae antigens. This fact has to be taken into account when allelic or genotypic data from patient samples are classified as low or high producers in this way without knowledge of the agent responsible for deregulated IL-10 expression $(4,30,31)$.

Family and twin studies have shown that IL-10 production is, at least, $50 \%$ influenced by genetic factors (31-33). It has been reported that a lower production of IL-10 from -819T carriers alters the binding affinity of nuclear transcription factors and -819T polymorphisms has also been implicated in leishmaniasis outcome (34).

However, our findings with respect to the SNP $-819 \mathrm{C} / \mathrm{T}$ are in agreement with the reported by Pereira and colleagues who suggests a definitive role for this SNP in leprosy in a population from the southeastern region of Brazil (35).

The concept of using polymorphisms to predict disease progression and early detection of a $M$. leprae hold promise (36). However consistent associations may be found if genotype assessment is performed discriminating ethnic and origin of the populations tested. The involvement of different IL-10 alleles, genotypes and extended haplotypes in the outcome of leprosy in different ethnic populations, suggests that $\mathrm{IL}-10$ region needs to be further investigated both in genetic and functional studies.

\section{Acknowledgments}

To Javier Gutiérrez for his contribution to this study.

\section{Conflict of interest}

The authors confirm that there are not conflicts of interest.

\section{Financial support}

This project was financed by Colciencias Cod. 325651928980, Heiser Program for Tuberculosis and Leprosy Research of the New Community
Trust, Instituto Colombiano de Medicina TropicalUniversidad CES, CODI Universidad de Antioquia, Sostenibilidad 2009-2010.

\section{References}

1. Alter A, Alcais A, Abel L, Schurr E. Leprosy as a genetic model for susceptibility to common infectious diseases. Hum Genet. 2008;123:227-35.

2. Bayley JP, Ottenhoff TH, Verweij CL. Is there a future for TNF promoter polymorphisms? Genes Immun. 2004;5:31529.

3. Eskdale J, Keijsers V, Huizinga T, Gallagher G. Microsatellite alleles and single nucleotide polymorphisms (SNP) combine to form four major haplotype families at the human interleukin-10 (IL-10) locus. Genes Immun. 1999;1:151-5.

4. Mörmann M, Rieth H, Hua TD, Assohou C, Roupelieva M, Hu SL, et al. Mosaics of gene variations in the interleukin-10 gene promoter affect interleukin-10 production depending on the stimulation used. Genes Immun. 2004;5:246-55.

5. Fife MS, Ogilvie EM, Kelberman D, Samuel J, Gutiérrez A, Humphries SE, et al. Novel IL-6 haplotypes and disease association. Genes Immun. 2005;6:367-70.

6. Fishman D, Faulds G, Jeffery R, Mohamed-Ali, Yudkin JS. The effect of novel polymorphisms in the interleukin-6 (IL-6) gene on IL-6 transcription and plasma IL-6 levels, and an association with systemic-onset juvenile chronic arthritis. J Clin Invest. 1998;102:1369-76.

7. Franceschi DS, Mazini PS, Rudnick CC, Sell AM, Tsuneto LT, Ribas ML, et al. Influence of TNF and IL10 gene polymorphisms in the immunopathogenesis of leprosy in the south of Brazil. Int J Infect Dis. 2009;13:493-8.

8. Hasan Z, Mahmood A, Zafar S, Khan AA, Hussain R. Leprosy patients with lepromatous disease have an upregulated IL-8 response that is unlinked to TNF-a responses. Int J Lepr Other Mycobact Dis. 2004;72:35-44.

9. Pravica V, Perrey C, Stevens A, Lee JH, Hutchinson IV. A single nucleotide polymorphism in the first intron of the human IFN-gamma gene: Absolute correlation with a polymorphic CA microsatellite marker of high IFN-gamma production. Hum Immunol. 2000;9:863-6.

10. Brinkman BM, Zuijdeest D, Kaijzel EL, Breedveld FC, Verjweij CL. Relevance of the tumor necrosis factor alpha (TNF alpha) - 308 promoter polymorphism in TNF alpha regulation. J Inflamm. 1995;46:32-41.

11. Schurr E, Gros P. A common genetic fingerprint in leprosy and Crohn's disease? N Engl J Med. 2009;361:2666-8. 
12. Blackwell JM, Black JF, Peacock CS, Miller EN, Sibthorpe D, Gnananandha D, et al. Immunogenetics of leishmanial and mycobacterial infections: The Belem family study. Philos Trans R Soc Lond B Biol Sci.1997;352:133145.

13. Cardoso CC, Pereira AC, Brito-de-Souza VN, DiasBaptista IM, Maniero VC, Venturini J, et al. IFNG +874 $\mathrm{T}>\mathrm{A}$ single nucleotide polymorphism is associated with leprosy among Brazilians. Hum Genet. 2010;128:481-90.

14. Moraes MO, Cardoso CC, Vanderborght PR, Pacheco AG. Genetics of host response in leprosy. Lepr Rev. 2006;77:189-202.

15. Stefani MM, Martelli CM, Gillis TO, Krahenbuhl JL, Brazilian Leprosy Study Group. In situ type I cytokine gene expression and mechanisms associated with early leprosy progression. J Infect Dis. 2003;188:1024-31.

16. Malhotra D, Darvishi K, Sood S, Sharma S, Grover Ch, Relhan V, et al. IL-10 promoter single nucleotide polymorphisms are significantly associated with resistance to leprosy. Hum Genet. 2005;118:295-300.

17. Franceschi D, Mazini P, Rudnick C, Sell A, Tsuneto L, Ribas M, et al. Influence of TNF and IL10 gene polymorphisms in the immunopathogenesis of leprosy in the south of Brazil. Int J Infect Dis. 2009;13:493-8.

18. Santos AR, Suffys PN, Vanderborght PR, Moraes MO, Vieira LM, Cabello PH, et al. Role of tumor necrosis factor-a and interleukin-10 promoter gene polymorphisms in leprosy. J Infect Dis. 2002;186:1687-91.

19. Moraes MO, Pacheco AG, Schonkeren JJ, Vanderborght PR, Nery JA, Santos AR, et al. Interleukin-10 promoter singlenucleotide polymorphisms as markers for disease susceptibility and disease severity in leprosy. Genes Immun. 2004;5:592-5.

20. Aggarwal S, Ali S, Chopra R, Srivastava A, Kalaiarasan $\mathbf{P}$, Malhotra D, et al. Genetic variations and interactions in anti-inflammatory cytokine pathway genes in the outcome of leprosy: A study conducted on a MassARRAY platform. J Infect Dis. 2011;204:1264-73.

21. Fitness J, Tosh K, Hill AV. Genetics of susceptibility to leprosy. Genes Immnun. 2002;3:441-53.

22. Scollard DM, Adams LB, Gillis TP, Krahenbuhl JL, Truman RW, Williams DL. The Continuing Challenges of Leprosy. Clin Microb Rev. 2006;2:338-81.

23. Isenberg $\mathbf{H}$, Della-Latta $P$, Weitzman I. Acid-fast stains. En: Isenberg H.D. Editor. Clinical microbiology procedures handbook. Secondnd edition. Washington, D.C: American Society for Microbiology; 1992.

24. Ridley RS, Jopling WH. Classification of leprosy according to immunity -a five group system. Int J Lepr.1966;34:22573.
25. Pardillo F, Fajardo T, Abalos R, Scollard D, Gelber R. Methods for the classification of leprosy for treatment purposes. Clin Infect Dis. 2007;44:1096-9.

26. Miller SA, Dykes DD, Polesky HF. A simple salting out procedure for extracting DNA from human nucleated cells. Nucleic Acids Res. 1988;16:1215.

27. Perrey C, Turner SJ, Pravica V, Howell WM, Hutchinson IV. ARMS-PCR methodologies to determine IL-10, TNFalpha, TNF-beta and TGF-beta 1 gene polymorphisms. Transpl Immunol. 1999;2:127-8.

28. Fitness J, Floyd S, Warndorff DK, Sichali L, Mwaungulu L, Crampin AC, et al. Large-scale candidate gene study of leprosy susceptibility in the Karonga district of Northern Malawi. Am J Trop Med Hyg. 2004;71:330-40.

29. Rojas W, Parra MV, Campo O, Caro MA, Lopera JG, Arias W, et al. Genetic make up and structure of Colombian populations by means of uniparental and biparental DNA markers. Am J Phys Anthropol. 2010;143:13-20.

30. Belgaumkar VA, Gokhale NR, Mahajan PM, Bhraradwaj RB, Pandit DP, Deshpande S. Circulating cytokine profiles in leprosy patients. Lepr Rev. 2007;78:223-30.

31. Reuss E, Fimmers R, Kruger A, Becker C, Rittner C, Hohler T. Differential regulation of interleukin-10 production by genetic and environmental factors - a twin study. Genes Immun. 2002;3:407-13.

32. Sinsimer D, Fallows D, Peixoto B, Krahenbuhl J, Kaplan G, Manca C. Mycobacterium leprae actively modulates the cytokine response in naive human monocytes. Infect Immun. 2010;78:293-300.

33. Moraes MO, Santos AR, Schonkeren JJ, Vanderborght PR, Ottenhoff TH, Moraes ME, et al. Interleukin-10 promoter haplotypes are differently distributed in the Brazilian versus the Dutch population. Immunogenetics. 2003;54:896-9.

34. Salhi A, Rodrigues Jr V, Santoro F, Dessein H, Romano A, Castellano LR, et al. Immunological and genetic evidence for a crucial role of IL-10 in cutaneous lesions in humans infected with Leishmania braziliensis. J Immunol. 2008;180:6139-48.

35. Pereira AC, Brito-de-Souza VN, Cardoso CC, DiasBaptista IM, Parelli FP, Venturini J, et al. Genetic, epidemiological and biological analysis of interleukin-10 promoter single-nucleotide polymorphisms suggests a definitive role for $-819 \mathrm{C} / \mathrm{T}$ in leprosy susceptibility. Genes Immun. 2009;10:174-80.

36. Bleharski JR, Li H, Meinken C, Graeber TG, Ochoa MT, Yamamura M, et al. Use of genetic profiling in leprosy to discriminate clinical forms of the disease. Science. 2003;301:1527-30. 